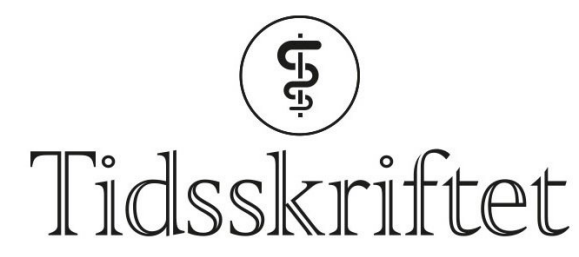

DEN NORSKE LEGEFORENING

\title{
Hvor mange døde tåler vi?
}

MINILEDER

\section{ARE BREAN}

Sjefredaktør

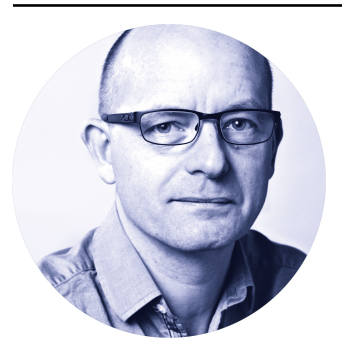

Optimistiske anslag tilsier at befolkningen i Norge kan være ferdig vaksinert mot covid-19 i midten av september 2021. Frem mot september må vi åpne samfunnet igjen, for de voldsomme restriksjonene har en høy - og økende - pris. Men selv med en gjennomvaksinert befolkning vil viruset fortsatt finnes - og det vil ta liv. Det må vi lære oss å leve med, slik vi lever med sesonginfluensa og andre smittsomme sykdommer.

Spørsmålet om når vi skal gjenåpne, er derfor et spørsmål om hvor mange tapte liv vi aksepterer, i bytte mot et åpent samfunn. Vi har en stilltiende aksept for at influensa koster noen hundre liv hvert år, uten at vi velger å stenge ned samfunnet av den grunn. Det er først og fremst et politisk valg, ikke et medisinsk. Når denne pandemien går mot slutten, må vi gjøre et lignende valg: Jo tidligere åpning, jo flere tapte liv. Jo senere åpning, jo større omkostninger for oss alle. Den ubehagelige debatten må vi forvente at våre politikere tar.

Publisert: 26. februar 2021. Tidsskr Nor Legeforen. DOI: 10.4045/tidsskr.21.04.01

(C) Tidsskrift for Den norske legeforening 2020. Lastet ned fra tidsskriftet.no 